\title{
A SURVEY STUDY ON ATTITUDES OF SPECIAL OLYMPIC GAMES VOLUNTEERS TOWARD THE INCLUSION OF INDIVIDUALS WITH INTELLECTUAL DISABILITIES IN CHINA \\ Chunxiao Li *, Lifang $\mathrm{Wu}^{* *}$
}

\author{
*National Institute of Education, Nanyang Techlogical University, Singapore \\ ${ }^{* *}$ School of Physical Education and Sports Science, Fujian Normal University, China
}

Currently no study investigates the extent of exposure to people with ID among Special Olympic Games (SOG) volunteers and the relationship between the exposure and attitudes toward the inclusion of individuals with ID. Thus, the present study was to investigate this gap. A crosssectional survey was conducted with three hundred and eighty six SOG volunteers for the $5^{\text {th }}$ (China) SOG in 2010. The results revealed that SOG volunteers were exposed to ID mainly through secondary sources (e.g., parents and mass media). There was a positive correlation between exposure to ID and attitude towards the inclusion of individuals with ID. There were no significant gender and age effects in attitude towards the inclusion of people with ID. It was suggested that the inclusion of people with ID in the Chinese social context can be advocated by increasing the exposure of the volunteers to people with ID.

KEYWORDS: people with special needs, integration, college students, sports games, attitudes toward inclusion

\section{INTRODUCTION}

The inclusion of individuals with disabilities has been advocated and implemented globally in the last few decades (Bailey, Barr, \& Bunting, 2001; Bigby, 2006; Hastings, Sjostrom, \& Stevenage, 1998; Lifeshitz \& Glaubman, 2002; Ouellette-Kuntz Burge, Brown, \& Arsenault, 2010; Xiao, 2005). Inclusion is a comprehensive concept which includes not only inclusive education (e.g., placing students with disabilities in regular schools or classes) but also social inclusion such as including people with disabilities into the community. Social inclusion has the potential to increase the interaction between those with and without disabilities (Freeman, 2000) and thus to improve the well-being and quality of life of individuals with intellectual disabilities (Cummins \& Lau, 2003).

In China, the increasing attention to the inclusion of people with disabilities is partially due to the increment of the population of people with disabilities. Since 1987, the Chinese population of people with disabilities has increased from 61 million to
83.86 million in 2006 (China Disabled Persons' Federation, 2009). The increased number of people with disabilities coupled with the rapid economic and social changes in the recent years has encouraged the Chinese policy makers to encourage inclusion in educational as well as vocational and recreational settings (Hampton \& Xiao, 2008). The government developed several policies and laws for supporting inclusive education in the late 1990s and the most significant one is called the "Learning in Regular Classroom" policy (Xiao, 2005). This policy requires that students with mild and moderate disabilities being integrated in regular education settings. Since the enactment of this policy, about $62 \%$ $(428,000)$ of all school-age children with disabilities $(686,000)$ are included in regular classroom settings (China Disabled Persons' Federation, 2010). Current laws and policies are also mandating in China to enhance the social inclusion. For example, the Sports Law requires that participation in physical 
activities should not discriminate people with disabilities (Wu \& Huang, 2008).

Despite the progress, China is still facing many challenges such as a lack of a comprehensive inclusive education policy, a shortage of education resources, and a lack of teacher preparation in terms of teaching both children with and without disabilities in the same classrooms (China Disabled Persons' Federation, 2010). In addition, another major barrier is the negative attitude of people without disabilities towards the inclusion of individuals with intellectual disabilities (ID; Baran, Aktop, \& Nalbant, 2009; Burge et al., 2007; Hampton \& Xiao, 2009).

A positive attitude towards individuals with ID is an integral component in ironing out the stigmatization of individuals with ID and insuring the implementation of the inclusion policies and laws (Ouellette-Kuntz et al., 2010). Because of the essential role of the attitude plays, it is crucial to investigate factors affecting attitudes toward individuals with disabilities (Hampton \& Xiao, 2007).

Previous investigations indicated that knowledge of ID was related to people's attitudes toward people with ID (Chan et al., 2002; Wong \& Wong, 2008). People (community residents, college students, and nursing home staff) with more knowledge on ID had more positive attitudes than those who had less knowledge (Chan et al., 2002; Hampton \& Xiao, 2008; Hunt \& Hunt, 2000; Wong \& Wong, 2008; Yazbeck et al., 2004). Demographic variables such as gender and age were founded to have some correlations with attitude towards individuals with ID but the findings were less consistent. Some reported that younger people and females tended to express more positive attitudes toward individuals with disabilities than older people and males in the Western countries (Krajewski \& Flaherty, 2000; Ouellette-Kuntz et al., 2010; Yazbeck et al., 2004). Others found that gender was not related to attitude towards ID in Chinese university students (Hampton \& Xiao, 2007). Thus, the relationship between demographic variables (i.e., age and gender) and attitude towards people with ID need to be further explored.
There were debates on whether the exposure to the individuals with ID can enhance the positive attitude towards this population. According to contact theory (Allport, 1954), prejudice and discrimination toward a minority group (individuals with ID as in this case) will be reduced through increasing contacts between people with and without ID (c.f., Allport, 1954; Slininger, Sherrill, \& Jankowski, 2000). Similarly, the theory of "mere exposure effect" which was founded on the basis of contact theory suggested that people without disabilities are expected to develop favourable attitudes toward people with ID when exposure to ID information (Rillotta \& Nettelbeck, 2007; Zajonc, 2001). Several researchers reported that people (college students, high school students, and children) who had more exposure or information related to individuals with ID held more favourable attitudes toward persons with ID than those with less contact or information (Chan et al., 2002; Chen et al., 2002; Krajewski \& Flaherty, 2000; Slininger et al., 2000). Others, however, argued that exposure to individuals with ID may not promote positive attitudes in teen or schoolaged students (e.g., Nowicki \& Sandieson, 2002; Krajewski et al., 2002). The above inconsistent findings again drive us to conduct this study.

Special Olympics, a sport movement founded in 1968 (accredited in 1988), is now becoming an international program with more than 3.4 million worldwide participants (Chursov, 2007). The mission of SOG is to create a better world by fostering the acceptance and inclusion of all people through the power of the sport movement (Special Olympics, 2011). In China, the National Special Olympics Games (NSOG) has been held once every four years since 1987 with the most recent NSOG (the $5^{\text {th }}$ ) held in Fuzhou in September 2010. Around 2000 athletes participated in the 11 sports (i.e., track and field, swimming, weightlifting, table tennis, badminton, bowling, roller skating, basketball, soccer, bocce, and judo). Without the enthusiastic commitments and supports of volunteers, Special Olympics 
would not attain internationally recognized achievements. A total of 2,108 volunteers were involved in providing services during the $5^{\text {th }}$ NSOG and $98 \%$ of them were college students.

In despite of the significant contributions by SOG volunteers, little research has been done to investigate psychological aspects of them (e.g., motivation for volunteering, attitudes toward inclusion). A very recent study (Khoo \& Engelhorn, 2011) although investigated the volunteers' motivations for delivering service in NSOG; we found no study investigating the attitudes of NSOG volunteers toward the inclusion of individuals with ID. Knowing how the impact of variables (i.e., age, gender, and previous exposure ID) on volunteers' attitudes toward inclusion may assist the SOG organizers in selecting volunteers. Therefore, the current study aimed to explore (a) prior-NSOG exposure to people with ID among NSOG volunteers in China; (b) age and gender effects in predicting attitudes toward the inclusion of people with ID; and (c) relationships between exposure to people with ID and attitudes toward the inclusion of people with ID.

\section{Method \\ Participants}

Participants of this survey study were volunteers for the $5^{\text {th }}$ NSOG of the People's Republic of China. Prior to distributing the questionnaire, a power analysis with a $95 \%$ Confidence Level was conducted using the Sample Size Calculator (Raosoft, Inc, 2004). The analysis yielded a sample size of 326 to detect a $\pm 5 \%$ margin of error for the targeted study population (2,108 SOG volunteers). Three hundred and eighty six volunteers completed the survey anonymously with 85.8 $\%(386 / 450)$ response rate. The sample size in the current study exceeded the minimum value (326) recommended by the analysis of sample calculation and was appropriate for the purpose of the study.

Of the 386 participants, 258 (67\%) were females and $128(33 \%)$ were males. Their age ranged from 18 to 33 years $(M=21.3, S D$
$=1.38)$. Volunteers were from different colleges in the University City in Fuzhou (China) and they would deliver service in the coming SOG events including bocce, soccer, and track and field. The majority of the participants were in those majors who did not have previous acquaintance with disability, such as education technology, English language and public management. Five participants were majoring in special education.

\section{Instruments}

The definition of ID in the current study was cited from American Association on Intellectual and Developmental Disabilities (AAIDD), which defined ID as people who both embody significantly below-average score on IQ test and limitedly exhibit a variety of capacity in daily life function (2011). Two instruments were used in this study. They are the Exposure to Mental Retardation (Siperstein et al., 2007) and the Mental Retardation Attitude Inventory Revised (Antonak \& Harth, 1994).

The Exposure to Mental Retardation (EMR, Siperstein et al., 2007) consists of eight questions that ask participants to indicate their exposure to individuals with ID. A sample item of the EMR is: "Have you ever read about intellectual disabilities?" Respondents answer each of the eight questions on a dichotomous yes/no scale ( $1=$ yes, $O=n o$ ). A total score of the EMR ranges from 0 to 8 . The internal consistency reliability of the EMR was .62 which is considered acceptable for exploratory studies (Siperstein et al., 2007). In the current study, the EMR was translated by a bilingual Chinese graduate student in special education and the bilingual investigators via back translation (Brislin, 1980). A native English speaker majoring in special education compared back-translated version with the original version of the EMR and the meaning of several words were reworded through this process.

The Mental Retardation Attitude Inventory-Revised (MRAI-R, Antonak \& Harth, 1994) was used to measure 
participants' attitudes toward the inclusion of individuals with ID. The MRAI-R consists of 29 items. A sample question of the MRAI-R is: "A child with intellectual disability should be integrated into regular classes in schools". A 4-point Likert scale ( 1 = Strongly Disagree, $4=$ Strongly Agree) is used for rating agreements from respondents. A total score of the MRAI-R is the sum of the responses given to the 29 items, which may range from 29 to 116. A higher score suggests more positive attitudes toward individuals with ID.

The MRAI-R has been examined and used in previous studies with Chinese college students (e.g., Hampton \& Xiao, 2007, 2008). The alpha reliability of the MRAI-R in Chinese college students was $.78-.82$ (Hampton \& Xiao, 2007, 2008). Besides the above-mentioned two instruments, demographic items for describing the participant's age, gender, and college major were added in the survey instruments.

\section{Procedures}

Permissions for administrating questionnaires were obtained from the $5^{\text {th }}$ NSOG Committee and the Research Committee of the Fujian Normal University. Questionnaires were administrated in a volunteer briefing assembly before SOG. Informed consent forms were collected from participants before administering the survey. Questionnaires were then distributed to volunteers by research assistants during the assembly. Instructions for completing the instruments were introduced by the second author. Participants were requested to complete the survey and then put the completed survey into the collection boxes.

\section{Data analysis}

SPSS 16.0 for Windows was used to analyze the data. Missing values $(0.02 \%)$ were treated by mean imputation (Kalton \& Kasprzyk, 1986). Descriptive analysis (i.e., mean $[\mathrm{M}]$, standard deviation [SD], percentage) was used to provide a profile of participants' demographic characteristics, EMR, and MRAI-R. Both the KolmogorovSmirnov test and the Shapiro-Wilk test demonstrated normality of the data. We examined the relationships among demographic variables (i.e., gender and age), exposure to people with ID, and attitudes toward the inclusion of individuals with ID through a hierarchical multiple linear regression method. The MRAI-R scores were regressed on age, gender, and EMR. Participants were divided into two age groups (i.e. 16-20 years, and 21-25 years).

\section{Results}

As shown in Table 1, most of the participants $(85 \%)$ indicated seeing a person with ID in a public place, followed by hearing about ID from schools $(84.2 \%)$ or from parents $(84.2 \%)$. Mass media was another major source for participants learning about ID (e.g., television [79.3\%] and movie [78.8\%]). Only $46.9 \%$ of them reported having talked with people with ID prior to their volunteer work at SOG. The MRAI-R mean scores of the participants ranged from 65-108 $(M=82.6, S D=6.95)$.

Table 2 presents the results of correlation analysis among age, EMR, and MRAI-R. EMR was positively correlated with the MRAI-R. However, age was not related to MRAI-R. In the regression analysis, gender and age cannot predict the MRAI-R, indicating no gender and age effects regarding attitudes toward inclusion of people with ID. After controlling demographic variables (i.e. age and gender), EMR was the major contributor to the prediction of the MRAI-R and it accounted for $2.7 \%$ of the variance in the MRAI-R, $F(3,382)=3.5, \beta=.16, p<.01$ (See Table 3). 
Table 1 Descriptive Statistics for EMR and MRAI-R $(n=386)$

\begin{tabular}{lccl}
\hline Scale & Percentages & Mean (SD) & Range \\
\hline$E M R$ & & & $0-1$ \\
Talked with person with ID & 46.9 & & \\
Read about ID & 55.2 & \\
Talk about ID with friends & 73.6 & & \\
Watched movie about ID & 78.8 & & \\
Watched television show about ID & 79.3 & & \\
Heard about people with ID from parents or adults & 84.2 & & \\
Heard about people with ID from school & 84.2 & & $0-8$ \\
Saw a person with ID in public place & 85.0 & & \\
Total score & & & \\
& & & \\
MRAI-R & & $82.67(1.66)$ & \\
Total score & & & \\
\hline
\end{tabular}

Note. ID = Intellectual Disability; EMR = Exposure to Mental Retardation; MRAI-R = Mental Retardation Attitude Inventory-Revised; SD = Standard Deviation.

Table 2 Correlations among Age, EMR, and MRAI-R $(n=386)$

\begin{tabular}{llll}
\hline Variable & Age & EMR & MRAI-R \\
\hline Age & 1 & $.27^{* *}$ & -.000 \\
EMR & 1 & $.15^{* *}$ \\
MRAI-R & & 1 \\
\hline Note ${ }^{* *} . p<.01 ;$ & EMR & Exposure to Mental Retardation; MRAI-R = Mental Retardation Attitude \\
Inventory.
\end{tabular}

Table 3 Summary of Hierarchical Regression Analysis for Age, Gender, EMR, and MRAI-R

\begin{tabular}{llll}
\hline Variable & $\beta$ & $R^{2}$ & $F$ \\
\hline Step 1 & & & \\
Age & -.02 & .00 & .59 \\
Gender & .05 & &
\end{tabular}

Step 2

$\begin{array}{llll}\text { Age } & -.06 & .03 & 3.5^{* *} \\ \text { Gender } & .05 & & \\ \text { EMR } & .16^{* *} & & \end{array}$

Note. ${ }^{* *} p<.01 ;$ EMR $=$ Exposure to Mental Retardation; MRAI-R $=$ Mental Retardation Attitude Inventory.

\section{Discussion}

This study focused on Chinese NSOG volunteers' exposure to people with ID prior to the Games and the relationship between the exposure and attitudes toward the inclusion of people with ID. Results of the study indicated that, before helping volunteers for the SOG, the participants gained the knowledge of ID mainly from secondary sources such as schools, parents, and the media. Only a small proportion of the volunteers had direct contact (e.g., personal talking) with people with ID. This finding is similar to the research conducted by Siperstein et al. (2007) who found that youth in regular school settings gained the knowledge of ID mainly from secondary sources. Although the participants volunteered to serve at SOG, they had few opportunities to interact with individuals with ID prior to the Game. 
The mean score of the MRAI-R in the current study was $82.6(S D=6.95)$ which was higher than the mean score $(M=78.04, S D=$ 7.15) reported in a previous study with non SOG volunteer Chinese college students in China (Hampton \& Xiao, 2007). The higher mean score of the MRAI-R in this study suggests that SOG volunteers may have more positive attitudes toward the inclusion of people with ID than other Chinese college students do. One reason for this finding could be that those students with more positive attitudes chose to become volunteers for the SOG, However, this assumption needs to be examined in future studies since there was no a control group in the current study. Measuring attitude pre and post volunteering, for example could be one way to follow. Furthermore, findings of this study indicated that SOG volunteers with more exposure to people with ID tended to have more favourable attitudes toward the inclusion of people with ID than those who had less exposure. The result was consistent with previous studies (e.g., Krajewski \& Flaherty, 2000; Siperstein et al., 2007; Slininger et al., 2000) that reported a positive relationship between exposure to disability in college students and attitudes toward people with ID, thus confirming the theory of mere exposure effect (Zajonc, 2001). However, exposure to individuals with ID only accounted for $2.7 \%$ of the variance in attitudes toward the inclusion of people with ID, suggesting most variance in attitudes may be explained by other factors (e.g., personality and motivations) rather than exposure. For example, Khoo and Engelhorn (2011) investigated volunteers' motivations for NSOG. Since relatedness (the universal want to interact or to be connected to others) is one of the construct of motivation (Baumeister \& Leary, 1995), it is expect that there is a relationship between SOG volunteers' motivation and their attitudes toward inclusion of people with ID.

The present study found that gender was not a predictor for attitudes toward inclusion of ID. The finding supports the results of the study conducted by Siperstein et al. (2007) which found that gender did not differ significantly on attitudes toward inclusion in college students and youth. The present result further supports that the difference in attitudes toward people with ID between Chinese males and females was minimal (Hampton \& Xiao, 2008).

Additionally, attitudes in SOG volunteers toward inclusion of people with ID were similar across age groups. This finding was consistent with the previous research on college students (Hampton \& Xiao, 2008) that reported non-significant age difference in attitudes toward people with ID. However, the result was inconsistent with previous studies involving students, disability service staff and community adults (e.g. Ouellette-Kuntz et al., 2010; Yazbeck et al., 2004). These inconsistent findings may be due to the varying sampling strategies (Nowicki \& Sandieson, 2002) or a narrow range of age groups in our participants.

\section{Implications of the Study}

The present study has several implications for practice. (a) Results of the current study indicated that exposure to individuals with ID was related to positive attitudes toward the inclusion of people with ID. Knowing this, institutions may increase their students' exposures to people with ID through activities (e.g., awareness training programs) which in turn may improve their attitudes towards inclusion. Since parents were found to play an important role in the development of the attitudes towards the inclusion of people with ID among the participants (Hampton \& Xiao, 2008), educational institutions may consider reaching out to parents and including them in the awareness training programs. (b) The current study indicated that the mass media was the main source of the knowledge of ID. Advocating for the inclusion of people with ID into society in the mass media may help people increase their exposure to the information on ID. (c) Future studies may explore whether training and exposure to SOG can enhance volunteers' positive attitudes on inclusion people with ID. 


\section{Limitations of the Study}

Several limitations of the study need to be acknowledged. (a) In the current study, exposure to ID only accounted for a small portion of the variance in attitudes towards inclusion. Future studies may explore whether other variables such as participants' motivation would account more variances in predicting attitudes towards inclusion. (b) The sensitivity of the instrument (i.e., EMR) used for the current study may have not been strong enough as exposure is a complex construct (Siperstein et al., 2007). Although the EMR provided useful information on SOG volunteers' exposure to people with ID in the current study, it may not fully explain the nature of the exposure. New instruments for measuring exposure may be developed in future studies. (c) As the sample of the current study was drawn from SOG volunteers who were college students from one geographic area, the results may not be generalized to, SOG volunteers who are not college students or college students who are not SOG volunteers.

\section{Conclusion}

This study added to the knowledge of sources of experience in Chinese SOG volunteers, and related them to attitudes toward persons with ID. It was found that demographic variables such as age and gender had limited values in predicting attitudes towards inclusion. We found that participants' previous exposure came mostly from the secondary source (e.g., media and parents) and therefore increasing exposure to ID in the mass media and university programs may enhance students' attitudes toward inclusion of persons with ID.

\section{REFERENCES}

AAIDD (2011). Intellectual disability. Retrieved 18 March, 2011, from http://www.aaidd.org/content_96.cfm?navI $\mathrm{D}=20$

Allport, G. W. (1954). The nature of prejudice. Cambidge, MA: Addison-Wesley. Antonak, R. F., \& Harth, R. (1994). Psychometric analysis and revision of the
Mental Retardation Attitude Inventory. Mental Retardation, 32, 272-280.

Bailey, A., Barr, O., \& Bunting, B. (2001). Police attitudes toward people with intellectual disability: An evaluation of awareness training. Journal of Intellectual Disability Research, 45, 344-350.

Baran, F., Aktop, A., \& Nalbant, S. (2009). Evaluation of a unified football program by Special Olympics athletes, partners, parents, and coaches. European Journal of Adapted Physical Activity, 2, 34-45.

Baumeister, R., \& Leary, M. R. (1995). The need to belong: Desire for interpersonal attachments as a fundamental human motivation. Psychological Bulletin, 117, 497-529.

Bigby, C. (2006). Shifting models of welfare: issues in relocation from an institution and the organization of community living. Journal of Policy and Practice in Intellectual Disabilities, 3, 147-154.

Brislin, R. W. (1980). Translation and content analysis of oral and written materials. In $\mathrm{H}$. C. Triandis \& G. W. Berry (Eds.), Handbook of cross-cultural psychology (pp. 398-444). Boston: Allyn \& Bacon.

Burge, P., Ouellette-Kuntz, H., \& Lysaght, R. (2007). Public view on employment of people with intellectual disabilities. Journal of Vocational Rehabilitation, 26, 229-239.

Chan, C. C., Lee, M. C., Yuen, H. K., \& Chan, F. (2002). Attitudes toward people with disabilities between Chinese rehabilitation and business students: An implication for practice. Rehabilitation Psychology, 47, 324-388.

Chen, R., Brodwin, M. G., Cardoso, E., \& Chan, F. (2002). Attitudes toward people with disabilities in the social context of dating and marriage: A comparison of American Taiwanese, and Singaporean college students. Journal of Rehabilitation, 68, 5-11.

China Disabled Persons' Federation (2009). The number of students in special schools. Fromhttp://www.cdpf.org.cn/tjsj/ndsj/2009/i ndexch.htm

China Disabled Persons' Federation (2010). Special education is facing five challenges. 
Fromhttp://www.spedu.net/Html/cjnews/20 1010/22861.html

Chursov, A. (2007). The campaign for Special Olympics: Celebrating growth. Retrieved from http://www.specialolympics.org

Cummins, R. A., \& Lau, A. L. D. (2003). Community integration or community exposure? A review and discussion in relation to people with disability. Journal of Applied Research in Intellectual Disabilities, 16, 145-157.

Freeman, S. F. N. (2000). Academic and social attainments of children with mental retardation in general education and special education settings. Remedial and Special Education, 21, 3-20.

Hampton, N. Z., \& Xiao, F. (2007). Attitudes toward people with developmental disabilities in Chinese and American students: The role of cultural values, contact, and knowledge. Journal of Rehabilitation, 73, 23-32.

Hampton, N. Z., \& Xiao, F. (2008). Psychometric properties of the Mental Retardation Attitude Inventory-Revised in Chinese college students. Journal of Intellectual Disability Research, 52, 299308.

Hampton, N. Z., \& Xiao, F. (2009). Traditional Chinese values and attitudes of Chinese university students toward people with intellectual disabilities. International Journal of Disability, Development, and Education, 56, 247-261.

Hastings, R. P., Sjostrom, K. E., \& Stevenage, S. V. (1998). Swedish and English adolescents' attitudes toward the community presence of people with disabilities. Journal of Intellectual Disability Research, 42, 246-253.

Hunt, B., \& Hunt, C. S. (2000). Attitude toward people with disabilities: A comparison of undergraduate rehabilitation and business major. Rehabilitation Education, 14, 269-283.

Kalton, G., \& Kasprzyk, D. (1986). The treatment of missing survey data. Survey Methodology, 12, 1-16.

Khoo, S., \& Engelhorn, R. (2011). Volunteer motivations at a National Special Olympics event. Adapted Physical Activity Quarterly, 28, 27-39.

Krajewski, J., \& Flaherty, T. (2000). Attitudes of high school students toward individuals with mental retardation. Mental Retardation, 38, 154-162.

Krajewski, J. J., Hyde, M. S., \& O'Keefe, M. K. (2002). Teen attitudes toward individuals with mental retardation from 1987-1998: Has inclusion made a difference? Education and Training in Mental Retardation and Developmental Disabilities, 35, 284-293.

Lifeshitz, H., \& Glaubman, R. (2002). Religious and secular students' sense of self-efficacy and attitudes towards inclusion of pupils with intellectual disabilities and other types of needs. Journal of Intellectual Disability Research, 46, 405-418.

Nowicki, E. A., \& Sandieson, R. (2002). A meta-analysis of school-age children's attitudes towards persons with physical or intellectual disabilities. International Journal of Disability, Development and Education, 49, 243-265.

Ouellette-Kuntz, H., Burge, P., Brown, H. K., \& Arsenault, E. (2010). Public attitudes towards individuals with intellectual disabilities as measures by the concept of social distance. Journal of Applied Research in Intellectual Disabilities, 23, 132-142.

Rillotta, F., \& Nettelbeck, T. (2007). Effects of an awareness program on attitudes of students without an intellectual disability towards persons with an intellectual disability. Journal of Intellectual and Developmental Disability, 32, 19-27.

Slininger, D., Sherrill, C., \& Jankowski, C. M. (2000). Children's attitudes toward peers with severe disabilities: Revisiting contact theory. Adapted Physical Activity Quarterly, 17, 176-196.

Siperstein, G. N., Norins, J., \& Mohler, A. (2006). Social acceptance and attitude change: Fifty years of research. In J. W. Jacoboson \& J. A. Mulick (Eds.), Handbook of intellectual and developmental disabilities (pp. 133-154). New York: Kluwer/Plenum.

Siperstein, G. N., Parker, R. C., Bardon, J. N., \& Widaman, K. F. (2007). A national study 
of youth attitudes toward the inclusion of students with disabilities. Exceptional Children, 73, 435-455.

Slininger, D., Sherrill, C., \& Jankowski, C. M. (2000). Children's attitudes toward classmates with severe disabilities: Revisiting contact theory. Adapted Physical Activity Quarterly, 17, 176-196.

Special Olympics (2011). Special Olympics Mission.Fromhttp://www.specialolympics.o $\mathrm{rg} /$ mission.aspx

Townsend, M. A. R., Wilton, K. M., \& Vakilirad, T. (1993). Children's attitudes toward peers with intellectual disability. Journal of Intellectual Disability Research, 37, 405-411.

Wong, P. K. S., \& Wong, D. F. K. (2008). Enhancing staff attitudes, knowledge and skills in supporting the self-determination of adults with intellectual disability in residential settings in Hong Kong: A pretest-posttest comparison group design.
Journal of Intellectual Disability Research, 52, 230-243.

Wu, Y., \& Huang, H. (2008). Integration and sharing: discussion on sustainable development of disabled sports in the harmonious perspective. China Sport Science, 28, 9-15.

Xiao, F. (2005). Mainstreaming in China: History, actuality, perspectives. Chinese Journal of Special Education, 3, 3-7.

Yazbeck, M., McVilly, K., \& Parmenter, T. R. (2004). Attitudes toward people with intellectual disabilities: an Australian perspective. Journal of Disability Policy Studies, 15, 97-111.

Zajonc, R. B. (2001). Mere exposure: A gateway to the subliminal. Current Directions in Psychological Science, 10, 225-228.

Corresponding author's e-mail address: cxlilee@gmail.com

\title{
EINE ÜBERBLICKSSTUDIE ZU EINSTELLUNGEN VON FREIWILLIGEN HELFERN BEI SPECIAL OLYMPICS-SPIELEN GEGENÜBER DER INKLUSION VON MENSCHEN MIT INTELLEKTUELLER BEHINDERUNG IN CHINA Chunxiao Li ${ }^{*}$, Lifang Wu ${ }^{* *}$
}

\author{
* National Institute of Education, Nanyang Techlogical University, Singapore \\ ** School of Physical Education and Sports Science, Fujian Normal University, China
}

Aktuell untersuchte noch keine Studie das Ausmaß des Kontakts zu Menschen mit intellektueller Behinderung (IB) unter den freiwilligen Helfern bei Special Olympics-Spielen (SOS) sowie die Relation zwischen Kontakt und Einstellungen gegenüber der Inklusion von Menschen mit IB. Daher möchte die gegenwärtige Studie diese Lücke füllen. Es wurde eine Querschnittsstudie mit 368 SOS-Freiwilligen der fünften nationalen Chinesischen Spiele 2010 durchgeführt. Die Resultate ergaben, dass die SOS-Freiwilligen hauptsächlich über sekundäre Bezugsquellen (z.B. Eltern oder Medien) zu intellektueller Behinderung Kontakt hatten. Es zeigte sich eine positive Korrelation zwischen Kontakten zu intellektueller Behinderung und der Einstellung gegenüber der Inklusion von Menschen mit IB. Es ergaben sich keine signifikanten Geschlechts- oder Alterseffekte in der Einstellung gegenüber der Inklusion von Menschen mit IB. Es wurde empfohlen, dass die Inklusion von Menschen mit IB im sozialen Kontext in China durch einen vermehrten Kontakt der Freiwilligen mit den betroffenen Menschen gefördert werden kann.

SCHLÜSSELWÖRTER: Menschen mit besonderen Bedürfnissen, Integration, College Studenten, Sportspiele, Einstellungen gegenüber Inklusion 


\begin{abstract}
(Аннотацця)
ОТНОШЕНИЕ УЧАСТНИКОВ СПЕЦИАЛЬНЫХ ОЛИМПИЙСКИХ ИГР К ВКЛЮЧЕНИЮ ЛЮДЕЙ С УМСТВЕННОЙ ОТСТАЛОСТЬЮ В КИТАЕ Чуньсяо Ли, Лифан Ву **

\author{
* Национальный институт образования, Технологический университет Сингапура г. \\ Наньяна \\ ** Школа физического воспитания и спортивной науки, Фуизянь педагогический \\ университет, Китай
}

В настоящее время нет исследований, посвященных изучению степени включения людей с умственной отсталостью в Специальные Олимпийские Игры (СОИ). Таким образом, цель данной статьи - ликвидировать этот пробел. Кросс-секционное исследование было проведено с триста восемьдесят шестью участниками 5-х Специальных Олимпийских Игр (Китай) в 2010 году. Результаты показали, что спортсмены СОИ подвергались умственной отсталости в основном благодаря вторичным источникам (например, родителей и средств массовой информации). Существовала положительная корреляция между подверженностью личности и отношением к включению лиц с умственной отсталостью. Существует значительное влияние пола и возраста, в отношении к интеграции людей с УО.
\end{abstract}

КЛЮЧЕВЫЕ СЛОВА: люди с особыми потребностями, интеграџия, студенты, спортивные игры, отночение к включению

\title{
ESTUDO DE PESQUISA SOBRE AS ATITUDES DOS VOLUNTÁRIOS DOS JOGOS SPECIAL OLYMPICS NO SENTIDO DA INCLUSÃO DE INDIVÍDUOS COM DEFICIÊNCIA INTELECTUAL NA CHINA Chunxiao Li ${ }^{*}$, Lifang $\mathrm{Wu}{ }^{* *}$
}

\author{
${ }^{*}$ National Institute of Education, Nanyang Techlogical University, Singapore \\ ** School of Physical Education and Sports Science, Fujian Normal University, China
}

Até ao momento nenhum estudo investigou a extensão da exposição dos voluntários dos Jogos Special Olympic (JSO) ao contacto com pessoas com DI e da relação entre essa exposição e as atitudes face à inclusão de indivíduos com DI. Assim sendo, o presente estudo pretendia investigar esta lacuna. Um estudo transversal foi realizado com trezentos e oitenta e seis voluntários dos JSO, $5^{\circ} \mathrm{JSO}$ (China) em 2010. Os resultados revelaram que os voluntários dos JSO foram expostos à DI principalmente através de fontes secundárias (ex: pais e media). Verificou-se uma correlação positiva entre a exposição à DI e as atitudes no sentido da inclusão das pessoas com DI. Não se verificaram efeitos significativos para as variáveis género e idade face às atitudes face à inclusão de pessoas com DI. Foi sugerido que a inclusão de pessoas com DI no contexto social Chinês pode ser preconizada através do aumento da exposição dos voluntários a pessoas com DI.

PALAVRAS-CHAVE: pessoas com necessidades especiais, integração, estudantes do secundário, jogos desportivos, atitudes face à inclusão 


\section{ESTUDO DE PESQUISA SOBRE AS ATITUDES DOS VOLUNTÁRIOS DOS JOGOS SPECIAL OLYMPICS NO SENTIDO DA INCLUSÃO DE INDIVÍDUOS COM DEFICIÊNCIA INTELECTUAL NA CHINA Chunxiao Li ${ }^{*}$, Lifang Wu**}

${ }^{*}$ National Institute of Education, Nanyang Techlogical University, Singapore

** School of Physical Education and Sports Science, Fujian Normal University, China

Até ao momento nenhum estudo investigou a extensão da exposição dos voluntários dos Jogos Special Olympic (JSO) ao contacto com pessoas com DI e da relação entre essa exposição e as atitudes face à inclusão de indivíduos com DI. Assim sendo, o presente estudo pretendia investigar esta lacuna. Um estudo transversal foi realizado com trezentos e oitenta e seis voluntários dos JSO, $5^{\circ} \mathrm{JSO}$ (China) em 2010. Os resultados revelaram que os voluntários dos JSO foram expostos à DI principalmente através de fontes secundárias (ex: pais e media). Verificou-se uma correlação positiva entre a exposição à DI e as atitudes no sentido da inclusão das pessoas com DI. Não se verificaram efeitos significativos para as variáveis género e idade face às atitudes face à inclusão de pessoas com DI. Foi sugerido que a inclusão de pessoas com DI no contexto social Chinês pode ser preconizada através do aumento da exposição dos voluntários a pessoas com DI.

PALAVRAS-CHAVE: pessoas com necessidades especiais, integração, estudantes do secundário, jogos desportivos, atitudes face à inclusão 